\title{
The Role of Corporate Governance on the Reduction of the Global Financial Crisis Implications: Evidence from Banking Sector of Jordan
}

\author{
Dr. Mo'taz Amin Al-Sa'eed (Assistant Professor) \\ Accounting and Accounting Information Systems Department \\ Al-Balqa' Applied University \\ Amman, Jordan \\ E-mail: motazalsaid@yahoo.com
}

Received: April 30, 2011

Accepted: September 7, 2011

Published: March 1, 2012

doi:10.5539/ijbm.v7n5p193

URL: http://dx.doi.org/10.5539/ijbm.v7n5p193

\begin{abstract}
This study aims to determine the role of Corporate Governance on the reduction of the global financial crisis implications on the Banking Sector of Jordan; in addition to that, it aims to review the latest CBJ regulation and directions which were issued during 2009 in order to motive the Jordanian Banks to expand the credit and lending to the public. In this study the researcher has used the CG Codes Pillars for Banks, and the monthly reports issued by CBJ. In order to reach the desired results, a postal questionnaire was sent to all of the risk managers and internal audit managers operating in the Jordanian Banks. The research results show that our respondents have good level of education and experience, a multiple regression test was carried out to test the relationship between the independent variables: Commitment to Corporate Governance, Functions of the Board of Directors, Board Committees, Control Environment, and Transparency and Disclosure codes, and the dependent variable: Reduction of the global financial crisis implications.; independent variables are able to explain nearly $77 \%(\mathrm{R}=0.765 \mathrm{P}<0.000)$ of the variance in Reduction of the global financial crisis implications, also it was found that calculated $\mathrm{F}=32.675$ is significant at 0.05 which means that there is an effect of independent variables on dependent variable. This indicates that there is a significant positive relationship between independent variables and (dependent variable). Thus, we reject the null hypotheses that assumed there is no significant role of independent variables. Meanwhile the coefficients factors and ( $\mathrm{T}$ value at 0.05 level of significant) support this suggestion when taking the independent variable jointly, By using the Stepwise analysis, the study has found that the most independent variable which plays the effective role on the reduction of the global financial crisis implications was the Transparency and Disclosure Pillars with $(\mathrm{R}=0.657)$. The study has found that the economy does not get the expected benefits from CBJ regulation. This study like other cross sectional studies is not free of limitations.
\end{abstract}

Keywords: Global financial crisis, Corporate governance, Central Bank of Jordan, IFRS, Risk management, Internal audit

\section{Introduction}

The financial crisis that began to take hold in 2007 has exposed significant weaknesses in the nation's financial architecture and in the regulatory system designed to ensure its safety, stability and performance. As asset prices deflated, so too did the theory that increasingly guided American financial regulation over the previous three decades - that private markets and private financial institutions could largely be trusted to regulate themselves.(Stein, 2009), During 2008, the stability of the global financial system came into question. Banks stopped lending to each other, thereby freezing credit globally. Global financial crisis is the worst financial events that swept the world since the Great Depression in the twenties of the past century, which almost led to the collapse of the global capital markets, which led, for example but not limited to the collapse of Merrill Lynch; and sold to the Bank of America. These events lead to a decline in societal wealth and welfare. Thus, if the firms can't ensure wealth and welfare of the community and the public interest; so that; will lead the governments to take charge of Corporate Governance, as in many countries of the world; where governments own many of the companies threatened to collapse. In light of this simplified analysis; This study aims to evaluate the role of 
Corporate Governance in reducing the global financial crises implications on the banks of Jordan, and to evaluate the role of regulations have been issued during 2009 by the Central Bank of Jordan in response to the global financial crises on the reduction of the global financial crises implications on the Banks of Jordan. This sector plays the primary role in sustaining the national economy, through revision of the principles of corporate governance legislation and the (OECD) principles, as well as instructions of the Central Bank of Jordan and its role in insuring the commitment of banks in the application of these instructions. Rezaee, et al, (2003) stated that good corporate governance promotes relationships of accountability among the primary corporate participants and this may enhance corporate performance as it holds management accountable to the board and the board accountable to the shareholders. One of the best-known definitions of corporate governance is to be found in the Report of the Committee on the Financial Aspects of Corporate Governance: Corporate governance is the system by which companies are directed and controlled. Boards of directors are responsible for the governance of their companies. CMA (2002) defined corporate governance as the process and structure used to direct and manage business affairs of the company towards enhancing prosperity and corporate accountability with the ultimate objective of realizing shareholders long-term value while taking into account the interest of other stakeholders. A number of commissions and committees have been established to address corporate governance in the USA, which include the Treadway Commission (1987) and the Blue Ribbon Committee (1999). Further, the Sarbanes-Oxely act of 2002 was signed into law and one of its major provisions was that listed companies establish audit committees (Joshi and Wakil, 2004). Firms with stronger monitoring by boards and shareholders may have taken more risk before the crisis, because managers that have accumulated firm-specific human capital and enjoy private benefits of control tend to seek a lower level of risk than shareholders that do not have those skills and privileges (Laeven and Levine, 2008).

This study has divided into five sections; the first one is concentrating on the introduction and research objectives, problem definition and research model, while the second one in focusing on the literature reviews that related to this study, the third section addresses the applied methodologies and procedures, while the final one figuring out he research findings and recommendations.

\section{Study Objective}

The objective of this research is to determine the role of corporate governance of the Central Bank of Jordan and regulations which were issued during 2009 on the reduction of the effect of the global financial crises implications on the banking sector of Jordan. After reviewing the literatures, motives for such researches are to evaluate and determine the feasibility of the corporate governance pillars applied by the Central Bank of Jordan. In addition to that; the study aims to evaluate to what extent do the regulations which were issued during 2009 by the Central Bank of Jordan - in response to the global financial crises - motive the Jordanian Banks to expand the credit and lending to the public. We found that this study is the first one up to the researcher's knowledge that determine and evaluate the role of corporate governance pillars on the reduction of the global financial crisis implications. A postal questionnaire has been developed and distributed to the Risk Managers and Internal Auditors.

\section{Problem Definition}

To achieve the research objective, the research problem can be represented by the following questions:

1) - What is the role of corporate governance on the reduction of the global financial crisis implications on the Banking Sector of Jordan?

The following questions can be derived from this problem that represents the problem elements:

a. What is the role of Commitment to Corporate Governance $(\mathrm{CG})$ on the reduction of the global financial crisis implications on the Banking Sector of Jordan?

b. What is the role of Functions of the Board of Directors on the reduction of the global financial crisis implications on the Banking Sector of Jordan?

c. What is the role of Board Committees on the reduction of the global financial crisis implications on the Banking Sector of Jordan?

d. What is the role of Control Environment on the reduction of the global financial crisis implications on the Banking Sector of Jordan?

e. What is the role of Transparency and Disclosure on the reduction of the global financial crisis implications on the Banking Sector of Jordan? 
2) -To what extent do the regulations which were issued during 2009 by the Central Bank of Jordan - in response to the global financial crises - motive the Jordanian Banks to expand the credit and lending to the public?

\section{Literatures Review}

They were many literatures relevant to this study; In the UK a number of issues in the early 1990's most notably the collapse of the Maxwell business empire, stimulated discussions and debate about structures for controlling executive power (Power 2002). A code of best practice was published in December 1992 (The Cadbury Code) which included recommendations for companies to establish audit committees comprising independent non-executive directors (Power 2002). In the USA an increasing number of earnings restatements by publicly traded companies, coupled with allegations of financial statement fraud and lack of responsible corporate governance of high profile companies (e.g. Enron, Global Crossing, World com in the USA, Parmalat in Italy and MacMed, Masterbond and Leisurenet in South Africa) has sharpened the ever increasing attention on corporate governance in general and audit committees in particular. The fall of these companies raised concerns regarding the lack of vigilant oversight by their boards of directors and audit committees in the financial reporting process and auditing functions (Rezaee et al, 2003). Gospel and Pendleton (2005) suggest that corporate governance essentially deals with the relationship between capital, management and labor. They say that "corporate governance is concerned with who controls the firm, in whose interest the firm is governed and the various ways whereby control is exercised.(2003), Kay and Silberston(1997) suggest a "trusteeship" model of corporate governance that emphasises "the evolutionary development of the corporation around its core skills and activities Corporate governance is about finance, about the relationship between employees, shareholders and management and about the evolutionary development of the core skills and activities of the corporation.

In its study of the corporate collapses at the beginning of this century (Enron and the like), the Economist Intelligence Unit (2003) concluded that 'companies are putting in place new governance processes but these processes do not necessarily lead to substantive changes; the form-over-substance problem is exemplified by efforts to supercharge the audit committee, rules and regulations may help shore up confidence in the market but they will not magically produce good behavior.

The legal protection of shareholder is the backbone of any corporate governance system. As a result, differences in legal protection of shareholders explain a substantial part of the differences in the ownership structures across countries (Shleifer \& Vishny, 1997). For instance, minority blockholder owners can exercise their rights only in countries with a developed legal system, whereas majority ownership is a more viable option in countries with a weak legal system (La Porta et al., 1998). In his study (Al-Sa'eed, 2011) has found that the compliance with Jordan Securities Commission requirements has been evaluated as the most effective feature that influence the financial reporting in the Jordanian share-traded companies. Audit quality, internal control effectiveness, and understanding of AC's functions are coming next respectively. The informal relations of trusts and importance of reputations are, however, also connected to the viability of dispersed ownership hence also explaining some of the differences in ownership structure across countries (Franks et al., 2009). Furthermore, the level of legal protection of shareholders has an impact on how well management ownership aligns the interests of management and shareholders. The government regulated deposit insurance and the implicit guarantee that large banks will be bailed-out by the government in order to avoid bank runs and hence maintain financial system stability, reduce the efficiency of corporate governance mechanisms (Berlin et al., 1991). Furthermore, both Demirguc-Kunt \& Detragiache (2002) and Barth et al. (2004) report that banking crises are more common in countries with generous deposit insurance systems. Moreover, the particular deposit insurance features, such as the funding and management of the system, have an even stronger connection to banking crisis than the mere existence of a deposit insurance system (Demirguc-Kunt \& Detragiache, 2002). During the current financial crises governments across the world have taken measurable actions. In addition to liquidity and lending guarantees, interest rate cuts, capitalization and asset purchases to bail-out troubled banks, the explicit deposit insurance coverage has been increased substantially (The Economist, October 6th, 2008, The Financial times, October 13th, 2008). Moreover, in October 2008 the European Commission presented a proposal for amending the Deposit Insurance Directive from 1994. In addition to the increase in the minimum deposit insurance coverage, time to payout in case of bank failure is reduced and the use of coinsurance is terminated as a result of the new rules. Some criticism has been raised towards aligning the deposit insurance systems of the EU countries. For example, Huizinga (2005) points out that the deposit insurance coverage in relation to the GDP is much higher in the new-EU countries than in the old-EU countries, hence resulting in over-insurance in some countries.

(Erkensa. D, .et al. 2009) investigated the role of corporate governance in the 2007-2008 financial crisis, using a unique dataset of 296 financial firms from 30 countries that were at the center of the crisis. Paradoxically, they 
found that while boards and shareholders appear to have executed their monitoring role by replacing poorly performing CEOs during the crisis, they also seem to have encouraged investments in subprime mortgage related assets that led to large losses during the crisis. Further exploration of the relation between governance and shareholder losses finds evidence consistent with shareholders having encouraged managers to take aggressive risks before the crisis, but does not find evidence consistent with boards having done so. Instead, there findings suggest that reputational concerns of board members explain why firms with more independent boards suffered from worse stock returns and recognized larger writedowns during the crisis. In particular, they found that firms with more independent boards were more likely to raise capital during the crisis, even though this came at a great cost to existing shareholders. In addition, they found that firms with more independent boards were more likely to disclose writedowns, which made it appear as if these firms recognized larger writedowns than other firms. Overall, results are inconsistent with the losses during the financial crisis being the result of lax oversight by boards and investors. Rather, results are consistent with risk-taking encouraged by shareholders and reputational concerns of directors having contributed to the losses. (Huizinga. H and Laeven.L, 2009) presented evidence of banks using accounting discretion to overstate the value of distressed assets. In particular, we show that the stock market applies far greater discounts to a bank's real estate loans and mortgage-backed securities than are implicit in the book values of these assets, especially following the onset of the U.S. mortgage crisis. This suggests that bank balance sheets overvalue real estate related assets during economic slowdowns. Caprio et al. (2007) examine the joint impact of shareholder protection laws and ownership characteristics on bank valuations while controlling for differences in bank regulation. They define the ultimate owners for the ten largest banks across 44 countries and categorise the bank as either widely held, controlled by a family or private individual, a state, a trust or foundation, a widely held non-financial corporation or a widely held financial company. They found that a great majority of the banks in the sample has concentrated ownership. When comparing the frequency of ownership type across countries with different regulatory environment, they found that widely held banks are more common in countries with strong shareholder protection and independent bank supervisory authority, that family ownership is more common in countries with strong bank supervisor authority, that state ownership is more common in countries with high restrictions on bank activities and low independence of bank supervisory authority. Moreover, they found that financial company ownership is more common in countries with strong shareholder protection, low restrictions on bank activities and low independence of bank supervisory authority, whereas non-financial company ownership is more common in countries with high independence of bank supervisory authority. On the joint impact of shareholder protection laws and ownership on bank valuation, which is the main focus of their study, Caprio et al. (2007) have found that the positive impact of ownership concentration on bank valuation is greater in countries where shareholder protection is weak. (Nogata.D, et.al, 2009) analyzed how corporate governance structures in an industrial country (Japan) affect firms' stock price performance during the current financial crisis. Results of this study show that Japanese firms that adopt stock option plans have suffered more from deteriorating stock price performance during the present financial crisis. Consistent with Adams (2009), this result suggests that managerial risk-taking incentives induced by stock-based compensations are responsible for declining firm performance during this crisis. Secondly, firms with more non-Japanese shareholders (cross-holding shareholders) experience larger (smaller) stock price reductions; Overall, results suggest that, for this financial crisis, corporate governance structures are important determinants of firm performance even in industrial countries. Finally, it is apparent that firms that rely on bank financing suffer more from deteriorating stock price performance. Similarly to results of existing studies, the results suggest that bank-dependent firms have difficulty in obtaining financing during a financial crisis. Previous studies have described that in emerging markets corporate governance structures affect stock price performance during the East Asian financial crisis (Baek et al., 2004; Johnson et al., 2000; Mitton, 2002; Lemmon and Lins, 2003). Those studies specifically examine emerging markets because minority shareholders' rights are not well protected in those markets (La Porta, 1998). For the case of the current financial crisis, however, it would be important to analyze how corporate governance structures affect stock returns in industrial countries such as the U.S. and Japan, where minority shareholders' rights are well protected.

\section{Hypothesis Development}

Based on the research questions and reviewing the literatures; study hypotheses have been developed as follows:

$\mathrm{H}$ 1: There is no role of corporate governance pillars on the reduction of the global financial crisis implications on banks of Jordan.

This hypothesis can be approved through approving the following sub-hypotheses:

H 1.1: There is no role of Commitment to Corporate Governance Pillars (CGP) on the reduction of the global financial crisis implications on the Banking Sector of Jordan. 
$\mathrm{H} \mathrm{1.2:} \mathrm{There} \mathrm{is} \mathrm{no} \mathrm{role} \mathrm{of} \mathrm{Functions} \mathrm{of} \mathrm{the} \mathrm{Board} \mathrm{of} \mathrm{Directors} \mathrm{Pillars} \mathrm{on} \mathrm{the} \mathrm{reduction} \mathrm{of} \mathrm{the} \mathrm{global} \mathrm{financial}$ crisis implications on the Banking Sector of Jordan.

$\mathrm{H}$ 1.3: There is no role of Board Committees Pillars on the reduction of the global financial crisis implications on the Banking Sector of Jordan.

H 1.4: There is no role of Control Environment on the reduction of the global financial crisis implications on the Banking Sector of Jordan.

$\mathrm{H}$ 1.5: There is no role of Transparency and Disclosure codes on the reduction of the global financial crisis implications on the Banking Sector of Jordan.

H 2: The regulations which were issued during 2009 by the Central Bank of Jordan - in response to the global financial crises - do not motive the Jordanian Banks to expand the credit and lending to the public?

\section{Research methodology}

Based on the aim of the study and review of the literatures, the study attempted to answer the following research question: What is the role of corporate governance pillars on the reduction of the global financial crisis implications on banks of Jordan? To get the appropriate responses to the first study question; A postal questionnaire survey was deemed the most appropriate research tools to answer the study questions. The questionnaire was contained of five parts that represent the corporate governance pillars which is Commitment to Corporate Governance (CGP), Functions of the Board of Directors, the board committees, Control Environment, and transparency and disclosure codes. It is an effective tool to seek opinions, attitudes and descriptions about role of corporate governance pillars. A listing of Share-Traded Jordanian Banks was available from the Amman Stock Exchange as of 31 December 2009. A total of 16 banks' Shares were traded on that day. It was decided to distribute the questionnaire to all those companies, unit of analysis were decided to be the risk managers and internal audit managers with confidence level of $95 \%$ and internal level of (10). The response rate of the questionnaire survey was (94\%), where only (30) out of (32) questionnaires were returned. In addition to that, an empirical analysis was conducted to evaluate the feasibility of regulations which were issued during 2009 by the Central Bank of Jordan in response to the global financial crises to motivate the Jordanian Banks to expand the credit and lending to the public.

\section{Data analysis and research findings}

The research sample (see table (1)) showed that (96\%) of the research sample hold Bachelor and Master Degrees which means that the research sample has sufficient level of education to answer the questionnaire items, while $(60 \%)$ of the respondents were specialized in accounting and management, this result is a good indicator about the respondents ability to understand the questionnaire items, on the other hand; nearly more than $(53 \%)$ of the respondents (10 years and above ) have a good level of experience to answer the research questionnaire without any difficulties. In the meantime; $(50 \%)$ of the respondents have a sufficient knowledge and training in Risk Management and Corporate Governance, which enhances the objectivity of answers, take into consideration that nearly (54\%) of the respondents have a continued follow up of the financial crises implications. Overall; the demographic features of the research respondents shows the target sample is relevant to answer the research questions.

\section{Insert Table 1 here}

\section{Descriptive Statistics}

Mean and standard deviation were used to describe attitudes of the Corporate Governance code Pillars, The study has found (see table (2)) that there are positive attitudes toward the Pillars concerning their role on the reduction of global financial crises implications; because their means were above the mean of the scale (3) (e.g. all the attitudes were above 4). It has found that the Transparency and Disclosure Pillar code has the highest mean (4.591); which means that this pillar code has the most effect on the reduction of the global financial crises implications on the Jordanian Commercial Banks; meanwhile the Functions of the Board of Directors Pillar code have the lowest mean (4.234).

\section{Insert Table 2 here}

As per table( 3); it's clear that the means and standard deviations for all the items were above the mean of the scale( 3); which represents a satisfactory indication about the importance and effect of each item on the reduction of the global financial crises implications on the Jordanian Commercial Banks. The most important items in the code pillars were belong to (Transparency and Disclosure Codes) in terms of disclosure and compliance with International Financial Reporting Standards (IFRS), compliance with changes in IFRS, maintaining the 
information channels with shareholders, depositors, financial markets counterparts, regulators and the public in general, the board acceptance of responsibility for the Bank's financial statements, and disclosure about the adequacy of internal controls with the means of ( $4.708,4.625,4.583$,and 4.416$)$ respectively.

\section{Insert Table 3 here}

\section{Kolmogorov-Smirnov Z Test}

(K-S) test was used to test the normality of the data (see table(4)) and it was found that calculated $\mathrm{Z}$ values are not significant at 0.05 levels which mean that the data is normally distributed.

\section{Insert Table 4 here}

\section{Testing of Research Hypothesis}

This study has used (t- test) for answering the research questions, Cronbach's Alpha test was used to test the reliability of the scale, the result was ( $\alpha=95.96 \%)$, is good because, it is greater than accepted value $60 \%$.

To test hypothesis, (t-test) was used to examine the role of independent variables: Commitment to Corporate Governance, Functions of the Board of Directors , Board Committees, Control Environment, and Transparency and Disclosure codes, and the dependent variable: reduction of the global financial crisis implications. The (t-test) analysis allows testing the strength of relationships between several independent variables and one dependent variable, which is the case in this study. The results of (t-test) (see Table(5)) shows that the independent variables have a significant role on the reduction of the global financial crisis implications, where (calculated t) is greater than the (tabulated t); Thus, further analysis becomes possible to examine the amount of variance in the dependent variables that can be explained by independent variables.

\section{Regression Analysis}

In order to test if the independent variables are able to explain the variance in the dependent variable, a multiple regression test was carried out to test the relationship between the independent variables: Commitment to Corporate Governance, Functions of the Board of Directors, Board Committees, Control Environment, and Transparency and Disclosure codes, and the dependent variable: Reduction of the global financial crisis implications.; independent variables are able to explain nearly $77 \%(\mathrm{R}=0.765 \mathrm{P}<0.000)$ of the variance in Reduction of the global financial crisis implications, also it was found that calculated $\mathrm{F}=32.675$ is significant at 0.05 which means that there is an effect of independent variables on dependent variable. This indicates that there is a significant positive relationship between independent variables and (dependent variable). Thus, we reject the null hypotheses that assumed there is no significant role of independent variables. Meanwhile the coefficients factors and ( $\mathrm{T}$ value at 0.05 level of significant) support this suggestion when taking the independent variable as jointly as follows: Commitment to Corporate Governance, $(9.094,0.00)$ Functions of the Board of Directors (11.715,0.00), Board Committees(12.268,0.00), Control Environment(12.269,0.00), and Transparency and Disclosure codes $(16.339,0.00$ ), while the overall $\mathrm{T}$ value for the main hypothesis (The role of Corporate Governance) is (14.091) which support the results the previous analysis.

Insert Table 5 here

\section{Stepwise analysis}

By using the Stepwise analysis to evaluate the role of corporate governance pillars, to determine the manner in which they reduce the implications of global financial crisis, it shows in table (6) that the most independent variable which plays the effective role on the reduction of the global financial crisis implications was the Transparency and Disclosure Pillars with $(\mathrm{R}=0.657)$. This result supporting that the Transparency and Disclosure Pillars are lined and complied with the requirements of the corporate governance principles that issued by the Organization of Economic Cooperation and Development (OECD), Those principles require the Banks to adapt the corporate governance principles to oversight the transparency and disclosure process as a function and responsibility of the management.

Insert Table 6 here

\section{Multicollinearity Test}

Variance Inflationary Factor (VIF) was used to test the multicollinearity of the variables (see table 7)); this test was used to verify that each independent variable is independent from other independent variables. It was found (see table (7)) that VIF $<5$, so that there is no multicollinearity which means that the model used in this research is correct.

Insert Table 7 here 
H 2: The regulations which were issued during 2009 by the Central Bank of Jordan - in response to the global financial crises - do not motive the Jordanian Banks to expand the credit and lending to the public?

Foreign currency reserves at the Central Bank of Jordan leapt by US\$ 25.9 billion or 0.2 percent, at the end of January 2010 compared with their level at the end of 2009; standing at US\$ 10,904.9 billion. The aforementioned level of reserves is equivalent to around 8.1 months of the Kingdom's imports of goods and services. Moreover, these reserves stood at US\$ $10,990.8$ billion as of February 25, 2010; up by US\$11.108 billion, compared with their level at the end of 2009.

Domestic liquidity at the end of January 2010 was up by JD 72.1 million, or 0.4 percent, compared with its level at the end of the previous year to total JD 20,085.4 million. Furthermore, our government issued a blanket guarantee for all deposits through 2009. The outstanding balance of the credit facilities extended by licensed banks increased by JD 84.1.9 million, or 0.6 percent, at the end of January 2010 compared with its level at the end of 2009; standing at JD 13,401.3 million.

\section{Insert Table 8 here}

For the first time during 2010, the CBJ slashed the interest rates on its monetary instruments by 50 basis points as of February 21, 2010. Accordingly, the aforementioned rates became as follows:

- $\quad$ Re-Discount Rate: 4.25 percent.

- $\quad$ Interest Rate on Overnight Repurchase Agreements: 4.00 percent.

- $\quad$ Overnight Deposit Window Rate: 2.00 percent.

In the light of the above rates; CBJ has tried to motivate the economy through this slash, meanwhile the Jordanian Commercial Banks did not fully response and comply with CBJ motives. We could discover this by reviewing the table (9) which includes the Macro Prudential Indicators in Jordanian Banks.

The table (9) shows the high capital adequacy of our banks (in excess of 12\% and around $19.3 \%$ ), the high liquidity ratios (in excess of $100 \%$ and around $155.6 \%$ ), and the low ratio of non-performing loans (around $6.4 \%$ ). and low of coverage ratio (around 48.9\%) that result from increasing nonperforming loans. Also Table (16) show low return on equity and return on assets (around $4.7 \%$ and $0.6 \%$ ) that result from decreasing in Jordanian banks income during 2009 and high leverage ratio (in excess of $6 \%$ around 13\%).

\section{Insert Table 9 here}

In the light of the second hypothesis, $\mathrm{CBJ}$ regulations which were issued in order to motivate banks to expand credit and loans, which in return expected to mobilize the economy. Again after reviewing the table (8) and explanation; the study has found that the economy does not get the expected benefits from CBJ regulation, and so the Jordanian Commercial Banks, especially when observing that most of Macro Prudential Indicators have increased. So that; the study has accepted the second hypothesis, in other words; the CBJ Regulations which were issued during 2009 do not motivate the banks to expand the credit and lending to the public.

\section{Conclusions and Recommendations}

The research results show that our respondents have good level of education and experience to answer the questionnaire items, $(60 \%)$ of the respondents were specialized in accounting and management, this result is a good indicator about the respondents ability to understand the questionnaire items, on the other hand; nearly more than $(53 \%)$ of the respondents (10 years and above) have a good level of experience to answer the research questionnaire without any difficulties. In the meantime; (50\%) of the respondents have a sufficient knowledge and training in Risk Management and Corporate Governance, which enhances the objectivity of answers, take into consideration that nearly (54\%) of the respondents have a continued follow up of the financial crises implications. In order to test if the independent variables are able to explain the variance in the dependent variable, a multiple regression test was carried out to test the relationship between the independent variables: Commitment to Corporate Governance, Functions of the Board of Directors, Board Committees, Control Environment, and Transparency and Disclosure codes, and the dependent variable: Reduction of the global financial crisis implications.; independent variables are able to explain nearly $77 \%(\mathrm{R}=0.765 \mathrm{P}<0.000)$ of the variance in Reduction of the global financial crisis implications, also it was found that calculated $F=32.675$ is significant at 0.05 which means that there is an effect of independent variables on dependent variable. This indicates that there is a significant positive relationship between independent variables and (dependent variable). Thus, we reject the null hypotheses that assumed there is no significant role of independent variables. Meanwhile the coefficients factors and ( $\mathrm{T}$ value at 0.05 level of significant) support this suggestion when taking the independent variable as jointly as follows: Commitment to Corporate Governance, $(9.094,0.00)$ Functions of the 
Board of Directors(11.715,0.00), Board Committees(12.268,0.00 ), Control Environment(12.269,0.00), and Transparency and Disclosure codes $(16.339,0.00)$, while the overall $\mathrm{T}$ value for the main hypothesis ( The role of Corporate Governance ) is (14.091) which support the results the previous analysis. These results are in line with prior studies (Erkensa. D, .et al. 2009), (Caprio et al. 2007), (Nogata.D, et.al, 2009) ,and (Adams ,2009). Overall, results suggest that, for this financial crisis, corporate governance structures are important determinants of firm performance even in industrial countries. Similarly to results of existing studies, the results suggest that bank-dependent firms have difficulty in obtaining financing during a financial crisis. Previous studies have described that in emerging markets corporate governance structures affect stock price performance during the East Asian financial crisis (Baek et al., 2004; Johnson et al., 2000; Mitton, 2002; Lemmon and Lins, 2003).

Mean and standard deviation were used to describe attitudes of the Corporate Governance code Pillars, The study has found that there are positive attitudes toward the Pillars concerning their role on the reduction of global financial crises implications; because their means were above the mean of the scale (3) (e.g. all the attitudes were above 4). It has found that the Transparency and Disclosure Pillar code has the most effect on the reduction of the global financial crises implications on the Jordanian Banks; meanwhile the Functions of the Board of Directors Pillar code have the lowest mean (4.234).

By using the Stepwise analysis to evaluate the role of corporate governance pillars, to determine the manner in which they reduce the implications of global financial crisis, it shows that the most independent variable which plays the effective role on the reduction of the global financial crisis implications was the Transparency and Disclosure Pillars with $(\mathrm{R}=0.657)$. This result supporting that the Transparency and Disclosure Pillars are lined and complied with the requirements of the corporate governance principles that issued by the Organization of Economic Cooperation and Development (OECD), Those principles require the Banks to adapt the corporate governance principles to oversight the transparency and disclosure process as a function and responsibility of the management. Variance Inflationary Factor (VIF) was used to test the multicollinearity of the variables; it was found that VIF $<5$, so that there is no multicollinearity which means that the model used in this research is correct. In the light of the second hypothesis, CBJ regulations which were issued in order to motivate banks to expand credit and loans, which in return expected to mobilize the economy. The study has found that the economy does not get the expected benefits from CBJ regulation, and so the Jordanian Banks, especially when observing that most of Macro Prudential Indicators have increased. According to those indicators the Jordanian banking does not expanding the Credit and lending to the public.

This study like other cross sectional studies is not free of limitations. The limitations should be seen as new opportunities for future research rather than deficiencies. Future research can apply the same research model in other context to proof the validity of the research model a cross context. Future research also can borrow the research model and apply longitudinal study to heal the cross sectional study problems. Based on the research results and limitations, practical recommendations can be provide as follows:

1 - Companies should establish the functions reserved to the board and those delegated to senior executives and disclose those functions. 2 - Companies should disclose the process for evaluating the performance of senior executives. 3 -The majority of the board should be independent non-executive directors. 4 - Companies should disclose the process for evaluating the performance of the board, its committees and individual directors. 5 Companies should establish a code of conduct and disclose the code or a summary of the code as to:

- The practices necessary to maintain confidence in the company's integrity

- The practices necessary to take into account their legal obligations and the reasonable expectations of their Stakeholders.

- The responsibility and accountability of individuals for reporting and investigating reports of unethical practices. 6 - Prudential supervision. 7 - Accounting and disclosure requirements. 8- Legal and judicial systems. 9- Market-based discipline. 10- Entry of foreign banks. 11- Capital controls. 12 - Restrictions on foreign-denominated debt. 13- Elimination of too-big-to-fail in the corporate sector. 14- Monetary policy and price stability. 15- Exchange rate regimes and foreign exchange reserves.16 - Facilitating the credit decisions.

\section{References}

Adams, R. (2009). Governance and Financial crises. [Online] Available: http://ssrn.com/abstract $=1398583$

Al-Sa'eed, M.A. (2011). Evaluation of the audit committee features and the manner they influence the financial reporting: Evidence from Amman Stock Exchange", ECMLG 2011, France -Nice (6-7 October 2011), Conference Accepted Paper. 
Baek, J-S., Kang, J-K., \& Park, K.S. (2004). Corporate governance and firm value: Evidence from the Korean financial crises. Journal of financial economics, Vol(7), No (1), 265-313.

Barth, J., Caprio, G., \& Levine, R. (2007). Bank regulations are changing: but for better or worse?. World Bank Policy Research Working Paper, 4646.

---- (2004). Bank regulation and supervision: what works best?. Journal of Financial Intermediation, Vol (13), No(2), 205-248.

Berlin, M., Saunders, A., \& Udell, G. (1991). Deposit insurance reform: what are the issues and what needs to be fixed?. Journal of Banking \& Finance, Vol(15), No(2). 735- 752.

Daisuke Nogata. D. et.al. (2009). Corporate governance and stock price performance during the financial crisis: Evidence from Japan. [Online] Available: http://ssrn.com/abstract=1501723

Demirguc-Kunt, A., \& Detragiache, E. (2002). Does deposit insurance increase banking system stability? An empirical investigation. Journal of Monetary Economics, Vol (4), No(9), 1373-1406.

Demirguc-Kunt, A., \& Kane, E. (2002). Deposit insurance around the globe: where does it work? Journal of Economic Perspectives, Vol (16), No (2), 175-195.

Demirguc-Kunt, A., Karacaovali, B., \& Laeven, L. (2005). Deposit insurance around the world: a comprehensive database. World Bank Policy Research Working Paper, 3628.

Erkens.D, et.al. (2009). Corporate Governance in the 2007-2008 Financial Crisis: Evidence from Financial Institutions Worldwide. [Online] Available: http://ssrn.com/abstract

Franks, J., Mayer, C., \& Rossi, S. (2009). Ownership: evolution and regulation. Review of Financial Studies, Vol (12), No(2).139-143.

Johnson, S., Boone, P., Breach, A., \& Friedman, E. (2000). Corporate governance in the Asian financial crisis. Journal of Financial Economics, Vol (58), No (3), 141-186.

Joshi, P.L and Wakil, A. (2004). A study of the audit committee function in the Bahrain: Empirical findings. Management Auditing Journal, Vol(19), No (7), 832-858.

Kay. J and Silberston. A. (1997). Corporate governance' in Fiona Macmillan Patfield (ed), Perspectives on Company Law: 2, (London, Kluwer Law International, 1997), p. 61.

La Porta, R., Lopez-de-Silanes, F., \& Shleifer, A. (2002). Government ownership of banks. Journal of Finance, Vol(57), No(1), 265-301.

La Porta, R., Lopez-de-Silanes, F., Shleifer, A., \& Vishny, R. (1998). Law and finance. Journal of Political Economy, Vol(106), No (6), 1113-1155.

Lemmon, M.L., \& Lins, K.V. (2003). Ownership structure, corporate governance, and firm value: Evidence from the East Asian Financial crisis. Journal of Finance, Vol (58), No(4), 1445-1468.

Mitton, T. (2002). A cross-firm analysis of the impact of corporate governance on the East Asian financial crisis. Journal of Financial economics, Vol (6), No(4), 215- 241.

OECD (Organisation for Economic Co-operation and Development). (2009b). Corporate Governance Lessons from the Financial Crisis, Directorate for financial and enterprise affairs - Steering Group on Corporate Governance, 23 February 2009.

Power, M. (2002). The audit society. Oxford University press, London.

Rezaee, R., Olibe, K.O and Minmier, G. (2003). Improving corporate governance: The role of audit committees. Managerial Auditing Journal, Vol (18), No (6/7):530 -537.

Shleifer, A., \& Vishny, R. (1997). A survey of corporate governance. Journal of Finance, Vol (52), No (2), 737-783. 
Table 1. Demographic characteristics of research respondents

\begin{tabular}{|l|l|l|l|}
\hline Level of Education & Frequency & Percent ( \%) & $\begin{array}{l}\text { Cumulative } \\
\text { Percent }\end{array}$ \\
\hline Bachelor & 16 & 54 & 54 \\
\hline M.sc & 12 & 40 & 96 \\
\hline PhD & 2 & 6 & 100 \\
\hline Total & $\mathbf{3 0}$ & $\mathbf{1 0 0}$ & \\
\hline Specialization & Frequency & Percent (\%) & $\begin{array}{l}\text { Cumulative } \\
\text { Percent }\end{array}$ \\
\hline Accounting & 16 & 53.3 & 53.3 \\
\hline Management & 2 & 6.7 & 60 \\
\hline Finance & 10 & 33.3 & 93.3 \\
\hline Economics & 2 & 6.7 & 100 \\
\hline Total & $\mathbf{3 0}$ & $\mathbf{1 0 0}$ & \\
\hline Experience & Frequency & Percent (\%) & $\begin{array}{l}\text { Cumulative } \\
\text { Percent }\end{array}$ \\
\hline Below 5 years & 0 & 0 & $\mathbf{0}$ \\
\hline above 5 years - below 10 years & 5 & 17 & $\mathbf{1 7}$ \\
\hline above 10years - below 15 years & 7 & 23 & $\mathbf{4 0}$ \\
\hline above 15 years - below 20years & 9 & 30 & $\mathbf{7 0}$ \\
\hline Above 20 years & 9 & 30 & $\mathbf{1 0 0}$ \\
\hline Total & $\mathbf{3 0}$ & $\mathbf{1 0 0}$ & \\
\hline Knowledge and training & Frequency & Percent(\%) & $\begin{array}{l}\text { Cumulative } \\
\text { Percent }\end{array}$ \\
\hline IFRS and IAS & 8 & 27 & $\mathbf{2 7}$ \\
\hline IAS( International Standards on Auditing ) & 4 & 13 & $\mathbf{4 0}$ \\
\hline Risk management & 7 & 23 & $\mathbf{6 3}$ \\
\hline Corporate Governance & 8 & 27 & $\mathbf{9 0}$ \\
\hline All of them & 3 & 10 & $\mathbf{1 0 0}$ \\
\hline Total & $\mathbf{3 0}$ & $\mathbf{1 0 0}$ & \\
\hline Follow up of the financial crises & Frequency & Percent (\%) & $\begin{array}{l}\text { Cumulative } \\
\text { Percent }\end{array}$ \\
\hline Continued & 16 & 54 & 54 \\
\hline At most & 10 & 33 & 87 \\
\hline Intermediate & 4 & 13 & 100 \\
\hline Total & $\mathbf{3 0}$ & $\mathbf{1 0 0}$ & \\
\hline & & & \\
\hline & 4 & & \\
\hline
\end{tabular}

Table 2. Mean and Standards Deviations

\begin{tabular}{|c|c|c|c|}
\hline \multicolumn{2}{|c|}{ Corporate Governance code Pillars } & Mean & Standard deviation \\
\hline 1 & Pillar Code1: Commitment to Corporate Governance. & 4.354 & .729 \\
\hline 2 & Pillar Code2: Functions of the Board of Directors & 4.234 & .516 \\
\hline 3 & Pillar Code3: Board Committees & 4.295 & .517 \\
\hline 4 & Pillar Code4: Control Environment & 4.296 & .513 \\
\hline 5 & Pillar Code5: Transparency and Disclosure & 4.591 & .477 \\
\hline
\end{tabular}


Table 3. Means and Standard Deviations per Item

\begin{tabular}{|c|c|c|}
\hline Items & Mean & S.D \\
\hline \multicolumn{3}{|l|}{ 1- Commitment to Corporate Governance: } \\
\hline $\begin{array}{l}\text { 1- The Bank has compiled this Code (Corporate Governance), which has been } \\
\text { approved by the Bank's Board and is published. }\end{array}$ & 4.500 & .7223 \\
\hline 2- The Bank has published the Code in his website. & 4.291 & .9545 \\
\hline $\begin{array}{l}\text { 3- The Bank has formed a corporate governance committee of the Board, to direct the } \\
\text { preparation, updating, and implementation of the Code. }\end{array}$ & 4.291 & .9079 \\
\hline 4- The Bank on an annual basis publicly reports its compliance with the Code & 4.333 & .8160 \\
\hline \multicolumn{3}{|l|}{ 2- The Functions of the Board of Directors: } \\
\hline $\begin{array}{l}\text { 5- The Board of Directors has overall responsibility for the operations and the financial } \\
\text { soundness of the Bank and ensures that the interests of shareholders, depositors, } \\
\text { creditors, employees, and other stakeholders, including the Central Bank of Jordan, are } \\
\text { met. }\end{array}$ & 4.625 & .5757 \\
\hline $\begin{array}{l}\text { 6- The Board sets the Bank's strategic goals, as well as overseeing the executive } \\
\text { management of the Bank. }\end{array}$ & 4.583 & .5835 \\
\hline $\begin{array}{l}\text { 7- The Board as a whole ensures and certifies that internal control systems are } \\
\text { effective. }\end{array}$ & 4.458 & .6580 \\
\hline 8- The Board ensures that all dimensions of the Bank's risk are managed properly. & 4.583 & .6538 \\
\hline 9- The position of Chairman of the Board is separated from that of General Manager. & 4.291 & 1.3344 \\
\hline 10- The Chairman ensures high standards of corporate governance by the Bank. & 4.333 & .6370 \\
\hline $\begin{array}{l}\text { 11- The Bank intends that the composition of the Board is determined in order to } \\
\text { obtain the optimal mix of skills and experience. }\end{array}$ & 4.250 & .7940 \\
\hline $\begin{array}{l}\text { 12- To foster an independent element within the Board, the Bank's policy is that the } \\
\text { Board should have at least three independent, non-executives, Directors. }\end{array}$ & 4.333 & .8681 \\
\hline 13- There is a formal annual evaluation of the General Manager by the Board. & 4.125 & .9469 \\
\hline $\begin{array}{l}\text { 14- The Board, through the Nominations and Remuneration Committee, at least } \\
\text { annually assesses its own performance as a Board. }\end{array}$ & 3.833 & 1.0901 \\
\hline $\begin{array}{l}\text { 15- The Board ensures that the Bank maintains a high degree of integrity in its } \\
\text { operations. Formal policies, including a Code of Conduct. }\end{array}$ & 4.250 & .8469 \\
\hline $\begin{array}{l}\text { 16- The Bank as part of its lending and credit approval process assesses the quality of } \\
\text { corporate governance in its corporate borrowers, especially public shareholding } \\
\text { companies. }\end{array}$ & 3.833 & .9163 \\
\hline $\begin{array}{l}\text { 17-The Bank assesses the strength or weakness of their corporate governance practice } \\
\text { in the borrower's risk assessment }\end{array}$ & 3.541 & .6580 \\
\hline \multicolumn{3}{|l|}{ 3- Board Committees } \\
\hline $\begin{array}{l}\text { 18- There is a formal and transparent process for appointments to the Board } \\
\text { Committees }\end{array}$ & 4.333 & .6370 \\
\hline $\begin{array}{l}\text { 19- The Audit Committee has all the duties and responsibilities required by the } \\
\text { Banking Law and other relevant laws and regulations, including the duties to } \\
\text { review:(20-22) }\end{array}$ & 4.458 & 6580 \\
\hline 20- The scope, results and adequacy of the Bank's internal and external audits & 4.708 & .5500 \\
\hline 21- The accounting judgments that are intrinsic to the financial statements & 4.500 & .6593 \\
\hline 22- The Bank's internal controls. & 4.541 & .5882 \\
\hline $\begin{array}{l}\text { 23- The Audit Committee has, by a specific provision in the written charter of its } \\
\text { functions and responsibilities, the ability to obtain any information from executive } \\
\text { management }\end{array}$ & 4.583 & .6538 \\
\hline $\begin{array}{l}\text { 24- The Nominations and Remuneration Committee comprises a minimum of three } \\
\text { non-executive Directors, the majority of which (including the Committee chairman) } \\
\text { are independent. }\end{array}$ & 4.041 & .9990 \\
\hline $\begin{array}{l}\text { 25-The Nominations and Remuneration Committee nominates all Board appointments, } \\
\text { duly considering candidates' abilities and qualifications }\end{array}$ & 3.666 & 1.0495 \\
\hline $\begin{array}{l}\text { 26- The Nominations and Remuneration Committee recommends to the Board the } \\
\text { remuneration (including monthly salary and other benefits) of each Director and the } \\
\text { General Manager. }\end{array}$ & 4.041 & .9545 \\
\hline
\end{tabular}




\begin{tabular}{|c|c|c|}
\hline $\begin{array}{l}\text { 27- The Nominations and Remuneration Committee ensures that the bank has a } \\
\text { remuneration policy, which is sufficient to attract and retain qualified individuals }\end{array}$ & 4.000 & .9325 \\
\hline $\begin{array}{l}\text { 28- The review of risk management is handled by a Risk Management Committee. } \\
\text { This Committee is comprised of Directors and may also include executive } \\
\text { management. }\end{array}$ & 4.250 & .6756 \\
\hline $\begin{array}{l}\text { 29- Risk Management Committee. reviews and approves the risk management } \\
\text { strategies and policies of the Bank }\end{array}$ & 4.416 & .8297 \\
\hline \multicolumn{3}{|l|}{ 4- Control Environment } \\
\hline $\begin{array}{l}\text { 30-The Bank's structure of internal controls is reviewed at least once a year by internal } \\
\text { and external auditors. }\end{array}$ & 4.458 & .7790 \\
\hline $\begin{array}{l}\text { 31- The Board provides a statement in each Annual Report on the adequacy of the } \\
\text { Bank's internal controls over its financial reporting. This statement contains }\end{array}$ & 4.458 & .5882 \\
\hline 32- The Bank’s established Internal Audit Committee & 4.500 & .8340 \\
\hline $\begin{array}{l}\text { 33- Bank should be adequately resourced, trained, remunerated, and be provided full } \\
\text { access to Bank records }\end{array}$ & 4.666 & .5646 \\
\hline $\begin{array}{l}\text { 34- The Internal Audit reports may be discussed with the departments and operational } \\
\text { units being reviewed }\end{array}$ & 4.500 & .8340 \\
\hline \multicolumn{3}{|l|}{$\begin{array}{l}* * \text { The primary responsibility of the Internal Audit function, conducting risk focused } \\
\text { audits, is at least the review of: } 35+36\end{array}$} \\
\hline $\begin{array}{l}\text { 35- The Bank's financial reporting (ensuring that significant financial, managerial, and } \\
\text { operating information are accurate, reliable, and timely). }\end{array}$ & 4.583 & .6538 \\
\hline $\begin{array}{l}\text { 36- compliance with internal policies, international standards, procedures, and } \\
\text { applicable laws and regulations }\end{array}$ & 4.583 & .7172 \\
\hline 37- The Bank requires the regular rotation of the external audit between auditing firms. & 3.500 & 1.1795 \\
\hline $\begin{array}{l}\text { 38- The external auditors' report is submitted to the Audit Committee as well as the } \\
\text { Annual General Assembly. The external auditors meet the Audit Committee, without } \\
\text { executive management present, at least once per year }\end{array}$ & 4.083 & 1.0598 \\
\hline \multicolumn{3}{|l|}{ **The responsibilities of the Bank's risk management department include: (39-46) } \\
\hline 39- the analysis of all risks including credit risk & 4.375 & .7109 \\
\hline 40- the analysis of all risks including market risk, & 4.291 & .7506 \\
\hline 41- the analysis of all risks including liquidity risk & 4.166 & .9168 \\
\hline 42- the analysis of all risks including operational risk; & 4.333 & .8165 \\
\hline 43- the development of methodologies for the measurement and control of each risk & 4.000 & .9325 \\
\hline $\begin{array}{l}\text { 44- the provision of information on risk metrics and on the Bank's risk profile to } \\
\text { Senior management and to the Board. }\end{array}$ & 4.041 & .8064 \\
\hline $\begin{array}{l}\text { 45- the provision of risk information for use in the Bank's public statements and } \\
\text { reporting. }\end{array}$ & 4.000 & .6593 \\
\hline $\begin{array}{l}\text { 46- The Bank's policy is that it has an independent compliance function which is } \\
\text { adequately resourced, trained and remunerated, in accordance with the Central Bank's } \\
\text { instructions in this regard. }\end{array}$ & 4.500 & .6593 \\
\hline \multicolumn{3}{|l|}{ 5- Transparency and Disclosure } \\
\hline $\begin{array}{l}\text { 47- The Bank is required to disclose in accordance with the International Financial } \\
\text { Reporting Standards (IFRS) and the Bank's own disclosure practices, beyond those } \\
\text { required by the Central Bank of Jordan. }\end{array}$ & 4.708 & .4643 \\
\hline $\begin{array}{l}\text { 48- The Bank is required to comply with all changes that have been happened in } \\
\text { accordance with the International Financial Reporting Standards (IFRS). }\end{array}$ & 4.625 & .4945 \\
\hline $\begin{array}{l}\text { 49- The Bank commits to maintaining the following information channels with its } \\
\text { shareholders, depositors, financial market counterparts, regulators and the public in } \\
\text { general }\end{array}$ & 4.625 & .5757 \\
\hline $\begin{array}{l}\text { 50- The Board accepts responsibility for the Bank's financial statements and the } \\
\text { contents of the Annual Report, for their accuracy, and for their completeness. }\end{array}$ & 4.583 & .5835 \\
\hline $\begin{array}{l}\text { 51- The Bank in its Annual Report includes statement by the Board of the adequacy of } \\
\text { internal controls. }\end{array}$ & 4.416 & .6538 \\
\hline
\end{tabular}


Table 4. K-S Z test

\begin{tabular}{|l|l|l|l|}
\hline \multicolumn{2}{|l|}{} & Z-Test & Z Sig \\
\hline H1 & Corporate Governance code & .819 & .513 \\
\hline H1-1 & Pillar Code1: Commitment to Corporate Governance. & 1.011 & .259 \\
\hline H1-2 & Pillar Code2: Functions of the Board of Directors & 1.047 & .223 \\
\hline H1-3 & Pillar Code3: Board Committees & .884 & .416 \\
\hline H1-4 & Pillar Code4: Control Environment & .584 & .885 \\
\hline H1-5 & Pillar Code5: Transparency and Disclosure & 1.235 & .513 \\
\hline
\end{tabular}

Table 5. T-test Results

\begin{tabular}{|l|l|l|l|}
\hline & Calculated T & Tabulated T & T Sig \\
\hline The role of Corporate Governance $\left(\mathrm{H}^{\mathrm{o}} 1\right)$ & 14.091 & 2.0687 & 0.000 \\
\hline Commitment to CG $\left(\mathrm{H}^{\mathrm{o}} 1.1\right)$ & 9.094 & 2.0687 & 0.000 \\
\hline Functions of The Board of Directors $\left(\mathrm{H}^{\mathrm{o}} 1.2\right)$ & 11.715 & 2.0687 & 0.000 \\
\hline Board Committees $\left(\mathrm{H}^{\mathrm{o}} 1.3\right)$ & 12.268 & 2.0687 & 0.000 \\
\hline Control Environment $\left(\mathrm{H}^{\mathrm{o}} 1.4\right)$ & 12.369 & 2.0687 & 0.000 \\
\hline Transparency and Disclosure $\left(\mathrm{H}^{\mathrm{o}} 1.5\right)$ & 16.339 & 2.0687 & 0.000 \\
\hline
\end{tabular}

Table 6. Variables Evaluation through Stepwise analysis and Regression

\begin{tabular}{|l|l|l|l|l|}
\hline Variables & $\mathrm{R}$ & $\mathrm{R}$ Square & $\begin{array}{c}\text { Adjusted R } \\
\text { Square }\end{array}$ & $\begin{array}{l}\text { Std. Error of the } \\
\text { Estimate }\end{array}$ \\
\hline Transparency and Disclosure. & .657 & .453 & .442 & .33515 \\
\hline Committed to Corporate Governance & .729 & .554 & .548 & .30440 \\
\hline Control Environment & .752 & .589 & .560 & .29400 \\
\hline Board Committees & .773 & .620 & .574 & .28409 \\
Functions of the Board of Directors & .793 & .647 & .589 & .27440 \\
\hline
\end{tabular}

Table 7. Multicolleniarity Test for Independent Variables

\begin{tabular}{|l|l|l|l|}
\hline \multirow{2}{*}{ Independent Variables } & \multicolumn{2}{|c|}{ Collinearity Statistics } \\
\cline { 2 - 4 } & Tolerance & VIF \\
\hline \multirow{3}{*}{} & Commitment to the CG & .536 & 1.867 \\
\cline { 2 - 4 } & Function of the Board of Directors & .357 & 2.798 \\
\cline { 2 - 4 } & Board Committees & .404 & 2.478 \\
\cline { 2 - 4 } & Control Environment & .732 & 1.367 \\
\cline { 2 - 4 } & Transparency and Disclosure & .734 & 1.363 \\
\hline
\end{tabular}


Table 8. Main Monetary Indicators: JD Million and Percentage Change Relative to the Previous Year (\%)

\begin{tabular}{|c|c|c|c|}
\hline \multirow{2}{*}{$\begin{array}{l}\text { Year } \\
2009\end{array}$} & & \multicolumn{2}{|c|}{ end of January } \\
\hline & & 2009 & 2010 \\
\hline $\begin{array}{l}\text { US\$ } 10,879 \\
40.5 \%\end{array}$ & CBJ's Foreign Exchange Reserves & $\begin{array}{l}\text { US\$ } 8,068.1 \\
4.2 \%\end{array}$ & $\begin{array}{l}\text { US\$10,904.9 } \\
0.2 \%\end{array}$ \\
\hline $\begin{array}{l}20,013.3 \\
9.3 \% \\
\end{array}$ & Money Supply (M2) & $\begin{array}{l}18,435.5 \\
0.7 \% \\
\end{array}$ & $\begin{array}{l}20,085.4 \\
0.4 \% \\
\end{array}$ \\
\hline $\begin{array}{l}13,317.2 \\
2.1 \%\end{array}$ & Credit Facilities, of which & $\begin{array}{l}13,203 \\
1.2 \% \\
\end{array}$ & $\begin{array}{l}13,401.3 \\
\% 0.6\end{array}$ \\
\hline $\begin{array}{l}12,041.3 \\
1.4 \% \\
\end{array}$ & Private Sector (Resident) & $\begin{array}{l}12,012.2 \\
1.2 \% \\
\end{array}$ & $\begin{array}{l}12,120.8 \\
0.7 \% \\
\end{array}$ \\
\hline $\begin{array}{l}20,298.4 \\
12.1 \% \\
\end{array}$ & Total Deposits, of which & $\begin{array}{l}18,334.9 \\
1.3 \% \\
\end{array}$ & $\begin{array}{l}20,499.5 \\
1.0 \%\end{array}$ \\
\hline $\begin{array}{l}15,865 \\
18.9 \% \\
\end{array}$ & In JD & $\begin{array}{l}13,746 \\
3.0 \% \\
\end{array}$ & $\begin{array}{l}16,078.5 \\
1.3 \% \\
\end{array}$ \\
\hline $\begin{array}{l}4,433.4 \\
-6.7 \% \\
\end{array}$ & In Foreign Currencies & $\begin{array}{l}4,588.9 \\
-3.5 \% \\
\end{array}$ & $\begin{array}{l}4,421 \\
-0.3 \% \\
\end{array}$ \\
\hline $\begin{array}{l}16,256.7 \\
13.7 \% \\
\end{array}$ & Deposits of Private Sector (Resident), of which & $\begin{array}{l}14,515 \\
1.6 \% \\
\end{array}$ & $\begin{array}{l}16,417.5 \\
1.0 \%\end{array}$ \\
\hline $\begin{array}{l}13,500 \\
19.5 \% \\
\end{array}$ & In JD & $\begin{array}{l}11,627.1 \\
2.9 \%\end{array}$ & $\begin{array}{l}13,686 \\
1.4 \% \\
\end{array}$ \\
\hline $\begin{array}{l}2,756.7 \\
-7.8 \% \\
\end{array}$ & In Foreign Currencies & $\begin{array}{l}2,887.9 \\
-3.5 \%\end{array}$ & $\begin{array}{l}2,731.5 \\
-0.9 \% \\
\end{array}$ \\
\hline
\end{tabular}

Source: Central Bank of Jordan / Monthly Statistical Bulletin.

Table 9. Macro prudential indicators in Jordan

\begin{tabular}{|l|l|l|}
\hline Macro prudential indicators & $\mathbf{2 0 0 8}$ & $\mathbf{2 0 0 9 / 6}$ \\
\hline capital adequacy ratio & $18.4 \%$ & $19.3 \%$ \\
\hline high liquidity ratio & 141.2 & 155.6 \\
\hline non-performing loans/ Total loans & 4.2 & 6.4 \\
\hline coverage ratio & 63.4 & 48.9 \\
\hline return on equity & 6.08 & 4.7 \\
\hline return on assets & 0.9 & 0.6 \\
\hline Leverage ratio & 12.9 & 13 \\
\hline
\end{tabular}

Source: Central Bank of Jordan / Monthly Statistical Bulletin 